\title{
Distribution of Selenium-Containing Proteins in Human Serum
}

\author{
Yuxi Gao, ${ }^{1,2}$ Yingbin LiU, ${ }^{3}$ Guilong Deng, ${ }^{3}$ \\ AND ZIJIAN WANG *,1 \\ ${ }^{1}$ State Key Laboratory of Environmental Aquatic Chemistry, \\ Research Center for Eco-Environmental Sciences, \\ Chinese Academy of Sciences, Beijing 100085, China; \\ ${ }^{2}$ Laboratory of Nuclear Analytical Techniques, Institute of High \\ Energy Physics, Chinese Academy of Sciences, Beijing 100039, \\ China; and ${ }^{3}$ The Second Affiliated Hospital, Zhejiang University \\ School of Medicine, Hangzhou 310009, China
}

Received December 17, 2003; Revised January 6, 2004;

Accepted January 30, 2004

\section{ABSTRACT}

Selenium-containing proteins in human serum of four volunteers in Beijing were separated and purified by preparative sodium dodecyl sulfate-polyacrylamide gel electrophoresis (SDS-PAGE). Selenium contents in the proteins were quantified by high-performance liquid chromatography (HPLC) coupled with a fluorescence detector (FLD) after pretreatment with a microwave digestion system and derivatization with 2,3-diaminonaphthalene (DAN). Five selenium-containing proteins with apparent molecular weights (MWs) of $68 \pm 3,57.5 \pm 2.5,47 \pm 2,41 \pm 1$, and $21 \pm 1 \mathrm{kDa}$, respectively, were detected. By comparison with known data on serum seleniumcontaining proteins, the $68 \pm 3 \mathrm{kDa}$ protein should belong to albumin, which took $6.3-9.8 \%$ of the total serum Se. The $57.5 \pm 2.5 \mathrm{kDa}$ protein should be selenoprotein $\mathrm{P}$ and the $47 \pm 2 \mathrm{kDa}$ protein was believed to be an isoform of selenoprotein $\mathrm{P}$. The sum of Se in selenoprotein P and its isomer took about $41.1-69.3 \%$ and was the major form of human serum selenium. The $21 \pm 1 \mathrm{kDa}$ protein should be plasma glutathione peroxidase (p-GPx) and its Se content was about $21.1-24.3 \%$. Also, protein of $41 \pm 1 \mathrm{kDa}$ should be a seleniumcontaining protein that, to our best knowledge, was reported for the first time. The Se percentage in this protein corresponded to $12.6-20.4 \%$ of total human serum Se.

Index Entries: Selenium; selenoprotein; human serum.

* Author to whom all correspondence and reprint requests should be addressed. 


\section{INTRODUCTION}

Selenium is an essential trace element for animals and humans. Selenium deficiency or a low selenium intake in conjunction with other stress factors could lead to various pathological changes. Previous studies have shown that more than $80 \%$ of body selenium was found to be protein bound (1). The beneficial effects of selenium were realized by several functional selenoproteins $(2,3)$. Whereas about 30 selenium-containing proteins or subunits in tissues of mammals have been reported (1,4-6), only a few of them (e.g., glutathione peroxidases [GPx] family, type-1 iodothyronine 5'deiodinase, and selenoprotein P) have been studied in detail. A few other selenoproteins have been sequenced and characterized, but their biological functions are yet unknown. All selenium-related health problems cannot be illuminated with known knowledge and the search for new selenoproteins and the study of their characteristics and biological functions has been continuing. Because of the complex composition and very low Se level in biological samples such as human serum, the search for new selenoproteins depends on the development of technique for protein separation and Se determination at an extremely low level in individual protein.

Approaches used in the separation of selenium-containing proteins in mammalian tissues include gel filtration chromatography $(7,8)$, affinity chromatography $(9,10)$, electrophoresis (7), and immunoassay (11). Selenium distribution among albumin, selenoprotein P, and plasma-GPx (pGPx) in human plasma or human serum was investigated by combining affinity chromatography with electrothermal atomic absorption spectroscopy $(12,13)$. The distribution of selenium-containing proteins in the human liver was also studied by gel filtration chromatography and hydride generation-atomic fluorescence spectrophotometry (HG-AFS) (14). However, affinity chromatography and gel filtration chromatography suffer from low resolution for protein separation. In addition, a large volume of effluents used dilutes the sample, making the subsequent steps more difficult. Electrophoresis, such as SDS-PAGE, is a protein-separation technique with high resolution, but the amount of protein and/or Se in each band is so small that a very sensitive method for Se determination is required. Identification of selenium-containing proteins in mammalian tissues has been successfully performed using electrophoresis after in vivo labeling with ${ }^{75} \mathrm{Se}$-selenite $(5,6)$. However, the ${ }^{75}$ Se-isotope technique can hardly be applied to the human tissues because of the long biological halflife of ${ }^{75} \mathrm{Se}$ and the radiation exposure.

In our previous work (15), selenium distribution among different soybean proteins was investigated by SDS-PAGE separation and high-performance liquid chromatography-fluorescence detector (HPLC-FLD) detection after derivatization with 2,3-diaminonaphthalene (DAN). Applying the same approach to human serum, four selenium-containing bands with a molecular-weight (MW) range of 57-74, 46-56, 40-42, and 21-22 $\mathrm{kDa}$, respectively, could be detected (16). With a view of subsequent 
Se determination, a large amount of serum was loaded to a $200 \times 10.5 \times 3$ $\mathrm{mm}$ gel, resulting in a low resolution of protein separation and large error of protein MW evaluation. Also, the contamination of samples resulting from the environment and reagents in a traditional wet-digestion procedure led to a higher detection limit of Se determination $(0.06 \mathrm{ng})$. Therefore, selenium-containing protein was semiquantitatively defined when its mean Se content exceeds twice the detection limit. Recently, a microwave preparation procedure was developed for selenium speciation in natural and drinking waters. The procedure used $\mathrm{HNO}_{3}$ as the digesting reagent and provided a detection limit of $0.0066 \mathrm{ng}$ (17). It could provide a much more precise tool for the estimation of a selenium-containing protein after SDS-PAGE separation.

In this article, a preparative SDS-PAGE procedure was used to separate and purify proteins in human serum and a microwave digestion procedure was applied to the determination of the Se amount in protein fractions. The aim of the work was to confirm and quantify selenium-containing proteins revealed in our previous work and to find new seleniumcontaining protein in human serum.

\section{EXPERIMENTAL}

\section{Sample Collection and Pretreatment}

Human blood samples were donated by four volunteers in the laboratory. Each $20 \mathrm{~mL}$ blood sample was put in a glass tube with neither anticoagulant nor heparin. The samples were left at room temperature for 20 $\mathrm{min}$ and were centrifuged at $2500 \mathrm{~g}$ for $15 \mathrm{~min}$. The supernatant was transferred into a clean tube and combined with 6 vol of Laemmli's buffer solution (18), which contained $50 \mathrm{mM}$ dithiothreitol (DTT; Sigma) as a reducing agent, $20 \mu \mathrm{M}$ leupeptin (Sigma, St. Louis, MO), $0.5 \mathrm{mM}$ phenylmethylsulfonyl fluoride (PMSF; Sigma), as well as $50 \mu M$ chymostatin (Sigma) as protease inhibitors. After mixing, the sample was boiled for 5 min and the insoluble material was removed by centrifugation at $10,000 \mathrm{~g}$ for $5 \mathrm{~min}$ to obtain the test solution. The test solution was used for immediate protein separation by SDS-PAGE.

\section{Protein Separation by Preparative SDS-PAGE}

Preparative SDS gel electrophoresis was performed in a Mini Prep Cell (Bio-Rad, Hercules, CA), using a discontinuous buffer system (18). Separating gel containing $9 \%$ acrylamide $(9 \mathrm{~cm}$ high and $3.7 \mathrm{~mm}$ in diameter, acrylamide : bis-acrylamide $=30: 8(\mathrm{w} / \mathrm{w})$, Bio-Rad) was polymerized in the Mini Prep Cell for separating and purifying 57-74 $\mathrm{kDa}$ and 46-56 kDa protein bands. Then, $12.5 \%$ acrylamide (the size and composition were the same as above) was used for $40-42 \mathrm{kDa}$ and $21-22 \mathrm{kDa}$ protein bands. On top of the separating gel, each was covered with $2 \mathrm{~cm}$ of $4 \%$ acrylamide as stacking gel. 
The test solution $(0.25 \mathrm{~mL})$ was loaded to the top of the stacking gel. Electrophoresis was run at a constant voltage $(200 \mathrm{~V})$ for $4 \mathrm{~h}$ until the bromophenol blue dye marker moved to $5 \mathrm{~mm}$ from the bottom of the separating gel. The buffer solution ( $50 \mathrm{mM}$ Tris- $\mathrm{HCl}, 384 \mathrm{mM}$ glycine, $0.1 \%$ SDS) (Bio-Rad) was pumped through the elution chamber at a rate of 100 $\mu \mathrm{L} / \mathrm{min}$. The elution chamber outlet was connected to a fraction collector and 100 fractions of each $0.5 \mathrm{~mL}$ were collected. Fraction number one contained the visible amounts of the bromophenol blue dye marker.

In order to locate the fractions that contain the selenium-containing proteins (i.e., those found in ref. 16), $5 \mu \mathrm{L}$ eluate from each fraction was loaded onto an analytical SDS-PAGE gel. After electrophoresis, the gel was then stained with $0.1 \% \mathrm{AgNO}_{3}$ for $30 \mathrm{~min}$ and visualized in $100 \mathrm{~mL}$ of $3 \%$ $\mathrm{Na}_{2} \mathrm{CO}_{3}$ containing $50 \mu \mathrm{L}$ of $37 \%$ formaldehyde (Beijing Chemical Co.) (19). According to the analytical results, fractions with the same protein composition were pooled together for selenium determination.

The relative MWs of the bands were calibrated by comparison of their relative mobility with that of the following marker proteins: phosphorylase $\mathrm{b}$ (rabbit muscle, $\mathrm{MW}=97.4 \mathrm{kDa}$ ), serum albumin (bovine, $\mathrm{MW}=66.2$ $\mathrm{kDa}$ ), ovalbumin (chicken egg, $\mathrm{MW}=42.7 \mathrm{kDa}$ ), carbonic anhydrase (bovine erythrocytes, MW $=31 \mathrm{kDa}$ ), and lysozyme (chicken egg white, MW = 14.4 K) (Shanghai Promega, China). Doubly deionized water was distilled using a quartz distiller and used throughout.

\section{Selenium Determination}

Fractions were digested by a CEM microwave digestion system (Model MDS-2000) with a microwave power from $0 \%$ to $100 \%(630 \mathrm{~W})$, the highest operating temperature of $200^{\circ} \mathrm{C}$, and the highest operating pressure of $1.38 \mathrm{MPa}\left(14.08 \mathrm{~kg} / \mathrm{cm}^{2}\right)$. The pooled fractions were mixed with 10 vol of $\mathrm{HNO}_{3}$ in a Teflon digestion vessel. After sealing, the vessels were placed at the symmetrical position on the turntable. The digestion was carried out following the working program listed in Table 1 (17).

Selenate in the digested solution was reduced to selenite in a hot water bath $\left(100^{\circ} \mathrm{C}\right)$ with an equal volume of concentrated hydrochloric acid as the reducing agent. After adding $0.5 \mathrm{~mL}$ of $0.1 \mathrm{M}$ EDTA and $1 \mathrm{~mL}$ of $2 \%$ hydroxylammonium chloride (Beijing Chemical Co.) to the selenite solution and adjusting its $\mathrm{pH}$ to $1.5-2.0$ with $5 \mathrm{M} \mathrm{NH}_{3} \cdot \mathrm{H}_{2} \mathrm{O}$ or $5 \mathrm{M} \mathrm{HCl}$, the mixture was added to $0.5 \mathrm{~mL}$ of $0.1 \%$ DAN solution, which was prepared by dissolving $100 \mathrm{mg}$ of DAN in $100 \mathrm{~mL}$ of $0.1 \mathrm{M} \mathrm{HCl}$, extracted with 25 $\mathrm{mL}$ cyclohexane five times, stored in a cool and lightproof condition, and covered with a 2-cm thickness of cyclohexane before use. The mixture was then heated at $50^{\circ} \mathrm{C}$ for $20 \mathrm{~min}$ and the fluorescent derivative, naphthoselenodiazol, was extracted into $0.5 \mathrm{~mL}$ of cyclohexane. The organic phase $(100 \mu \mathrm{L})$ was injected into normal phase HPLC (Waters 201 HPLC W /510 with a Shimadzu RF-535 fluorescence detector at 366/520 nm) and a $\mu$ Porasil $\mathrm{C}_{18}-\mathrm{NH}_{2}$ column. The mobile phase was a mixture of cyclohexane 
Table 1

Working Programs of the Microwave System

\begin{tabular}{ccccc}
\hline Step & Power $/ \%$ & Pressure $/ \mathrm{MPa}$ & Time $/ \mathrm{min}$ & Notes \\
\hline 1 & 100 & 0.55 & 5 & Rising of temperature \\
2 & 80 & 0.55 & 10 & Constant pressure \\
3 & 0 & & 10 & For pressure restore \\
4 & 100 & 0.55 & 5 & Rising of temperature again \\
5 & 80 & 0.55 & 10 & Constant pressure \\
\hline
\end{tabular}

and tetrahydrofuran $(9: 1, \mathrm{v} / \mathrm{v})$. The signal of naphtho-selenodiazol in the chromatogram was characterized by its retention time, which was determined using a naphtho-selenodiazol standard prepared in our laboratory. Relative fluorescent intensity was recorded as peak height for calculating Se content according to the calibration curve. The same volume of the buffer solution was executed under the same conditions and the value was used as the blank. The Se content in a protein band was obtained from the difference between the sample and the blank.

To calibrate the Se determination, a stock solution of selenite (100 $\mathrm{mg} / \mathrm{L}$ ) was prepared by dissolving known amounts of sodium selenite in $0.1 \mathrm{M} \mathrm{HCl}$ and diluting to a final concentration of $1 \mathrm{ng} / \mathrm{mL}$ before use. The calibration was carried out together with sample measurement. The calibration curve was obtained by adding $0-1.5 \mathrm{ng}$ Se to $2 \mathrm{~mL}$ distilled water, following by the same procedure for sample determination. The validity of the quantitative method was examined by using a certified reference material, rice flour of Japan Environmental Agency (NIES 10) with a Se content of $60 \mathrm{ng} / \mathrm{g}$, in parallel with the Se determination in proteins.

\section{RESULTS AND DISCUSSION}

\section{Separation and Identification of Selenium-Containing Proteins in Human Serum}

The recoveries of Se from standard reference material were $99.4 \pm 2 \%$ $(N=3)$. Ten replicated determinations for the reagent blank were performed on $2 \mathrm{~mL}$ of distilled water. The result was $0.0205 \pm 0.0022 \mathrm{ng}$ Se, which corresponds to a detection limit of $0.0066 \mathrm{ng}$ Se (three times the standard deviation). 


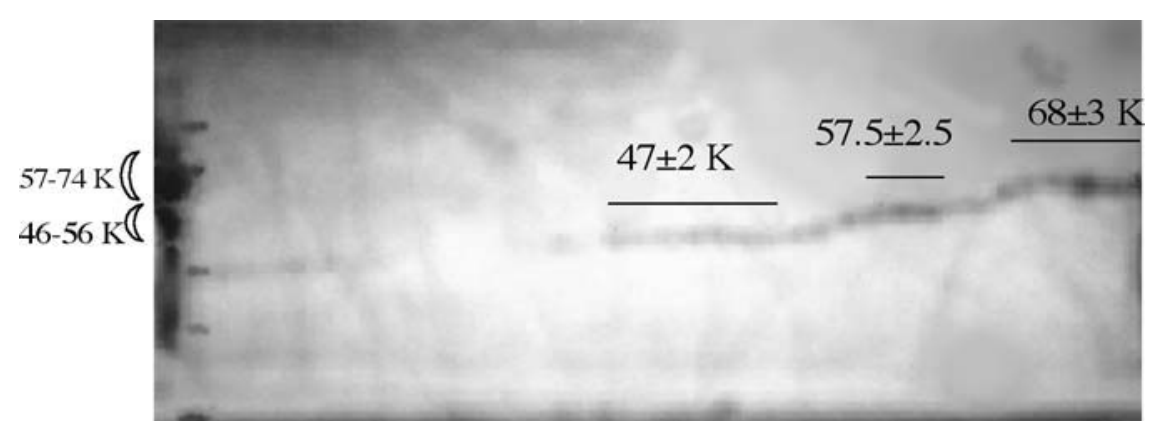

Fig. 1. Silver-stained analytical SDS-PAGE gel of fractions from a preparative SDS-PAGE cell with 9\% acrylamide separating gel. Lane 1, human serum; lane 2, molecular-weight-marker proteins (from top to bottom: 97.4, 66.2, 42.7, 31, and $14.4 \mathrm{kDa}$ ); lane 3-30, fraction number 30, 32, and 34-84, respectively.

A typical silver-stained analytical SDS-PAGE gel for fractions numbered 30, 32, and 34-84 is shown in Fig. 1. It can be seen that there was generally one visualized band in each fraction collected from the Mini Prep Cell. The molecular weights of the protein bands were estimated by comparing with the standard proteins in the left lane of the chromatogram. Nine protein bands with MWs of 46, 47, 49, 54, 57.5, 60, 66, 68, and $73 \mathrm{kDa}$, respectively, were separated from the two selenium-containing bands (MW range $=46-56$ and 57-74 kDa) detected in our previous work (16).

Three replicated protein separations and Se determinations were performed on each of four human serum samples. Only proteins with a mean Se content exceeding the detection limit $(0.0066 \mathrm{ng} \mathrm{Se})$ were considered to be selenium-containing proteins. Thus, five selenium-containing proteins with apparent MWs of $68 \pm 3,57.5 \pm 2.5,47 \pm 2,41 \pm 1$, and $21 \pm 1 \mathrm{kDa}$ could be detected in human serum. The Se contents of the five proteins are given in Table 2.

Selenium is known to incorporate into at least three plasma proteins $(20,21)$ (i.e., albumin, selenoprotein $\mathrm{P}$, as well as p-GPx). In our previous work (16), four selenium-containing bands with a MW range of 57-74, 46-56, 40-42, and 21-22 kDa were detected. Among them, the 57-74 kDa bands were the most abundant selenium-containing bands. According to their MW range and selenium content, we concluded that the band should contain two selenium-containing proteins: albumin (reported MW $=69$ $\mathrm{kDa})$ and selenoprotein $\mathrm{P}(\mathrm{MW}=57 \mathrm{kDa})$. The band of albumin, the most abundant protein in human serum, was so wide that other bands near it can hardly be identified. In this study, a preparative SDS-PAGE system was used especially to separate and purify the two selenium-containing proteins. Two selenium-containing bands were found in this MW range (see Fig. 1 and Table 2). The $68 \pm 3 \mathrm{kDa}$ protein was believed to be albumin, which incorporates selenomethionine at the site of methionine in a nonspecific and unregulated manner $(8,13,22)$. In fact, the unspecific incorporation of selenomethionine occurs in all proteins. Other unspecific selenium-containing 
Table 2

Se Amounts (ng) in the Five Selenium-Containing Proteins of Human Serum from Four Healthy Adults $(n=3)$

\begin{tabular}{ccccc}
\hline Samples No. & 1 & 2 & 3 & 4 \\
\hline $68 \pm 3 \mathrm{~K}$ & $0.12 \pm 0.01$ & $0.15 \pm 0.02$ & $0.29 \pm 0.12$ & $0.22 \pm 0.08$ \\
$57.5 \pm 2.5 \mathrm{~K}$ & $0.58 \pm 0.05$ & $0.76 \pm 0.13$ & $0.80 \pm 0.15$ & $1.00 \pm 0.20$ \\
$47 \pm 2 \mathrm{~K}$ & $0.19 \pm 0.06$ & $0.44 \pm 0.05$ & $0.78 \pm 0.15$ & $1.09 \pm 0.02$ \\
$41 \pm 1 \mathrm{~K}$ & $0.31 \pm 0.04$ & $0.30 \pm 0.08$ & $0.37 \pm 0.12$ & $0.44 \pm 0.10$ \\
$21.5 \pm 1 \mathrm{~K}$ & $0.32 \pm 0.06$ & $0.50 \pm 0.11$ & $0.72 \pm 0.14$ & $0.75 \pm 0.04$ \\
\hline
\end{tabular}

protein can hardly be detected because of the lower protein contents in comparison to albumin. Albumin can also bind selenide to 1 of its 17 disulfide bonds when participating in the metabolism of selenite $(23,24)$. The selenide would be lost in the process of SDS-PAGE separation.

The $57.5 \pm 2.5 \mathrm{kDa}$ protein should be selenoprotein $\mathrm{P}$, the major selenoprotein in human serum. Recent studies have revealed that there exists at least two isoforms of the protein in rat and human plasma (25-29). One isoform, MW of $45 \mathrm{kDa}$ for rat and $51 \mathrm{kDa}$ (28) and $55 \mathrm{kDa}$ (29) for humans, is a truncated protein with termination of protein synthesis occurring at the second selenocysteine codon. The $47 \pm 2 \mathrm{kDa}$ selenium-containing band observed in this study was probably an isoform of selenoprotein P. In conventional Sephadex gel chromatography, these two bands cannot be separated. The $21 \pm 1 \mathrm{kDa}$ band should be the subunit of $\mathrm{p}-\mathrm{GPx}$, which is a tetramer composed of four identical 22-kDa subunits and each subunit contains one selenocysteine residue at its active site.

Among the five selenium-containing bands detected, the $41 \pm 1 \mathrm{kDa}$ band has not been reported so far. Because the protease inhibitors were added to the serum immediately, they were unlikely the fragments of large selenoproteins produced by accidental proteolytic decomposition. The selenium-containing band might be a dimer of the subunits of p-GPx, originating from an incomplete dissociation of the multimeric selenoenzyme; still, it might be a newly found selenium-containing protein. In any case, further studies to confirm, identify, and characterize the protein bands are necessary.

\section{Selenium Distribution in Human Serum}

The Se distribution among the five selenium-containing protein bands is listed in Table 3. It could be seen that $6.3-9.8 \%$ of detected Se was present 
Table 3

Percentage of Se in the Five Proteins to Total Recovered Se (\%)

\begin{tabular}{ccccc}
\hline Samples No. & 1 & 2 & 3 & 4 \\
\hline Se levels in samples $(\mathrm{ng} / \mathrm{mL})$ & $56 \pm 4$ & $72 \pm 8$ & $115 \pm 5$ & $131 \pm 5$ \\
$68 \pm 3 \mathrm{~K}$ & -7.9 & -7.0 & -9.8 & $-^{6.3}$ \\
$57.5 \pm 2.5 \mathrm{~K}$ & -38.2 & -35.3 & -27.0 & $-^{28.6}$ \\
$47 \pm 2 \mathrm{~K}$ & -12.5 & -20.1 & -26.4 & -31.1 \\
$41 \pm 1 \mathrm{~K}$ & 20.4 & -14.0 & -12.5 & -12.6 \\
$21.5 \pm 1 \mathrm{~K}$ & 21.1 & -23.3 & -24.3 & -21.4 \\
Se recovery (\%) & 82.2 & 90.3 & 77.9 & 81.0 \\
\hline
\end{tabular}

in album, $21.2-24.3 \%$ in $\mathrm{p}-\mathrm{GPx}, 12.6-20.4 \%$ in the $41 \pm 1 \mathrm{kDa}$ protein, $28.6-38.2 \%$ in selenoprotein $\mathrm{P}$, and $12.5-31.1 \%$ in the $47 \pm 2 \mathrm{kDa}$ protein. Considering that the $47 \pm 2 \mathrm{kDa}$ protein might be one isoform of selenoprotein $\mathrm{P}$, Se in selenoprotein P could take about $50.7-59.7 \%$ of the recovered Se. Obviously, this fraction was the most abundant selenoprotein in the samples. The Se distribution in serum or plasma reported by several authors is listed in Table 4. For the three reported selenium-containing proteins (albumin, selenoprotein $\mathrm{P}$, and $\mathrm{p}-\mathrm{GPx}$ ), our result was comparable with those values of human plasma or serum reported by Harrison et al. (12) and Plecko et al. (13), but was slightly different from that reported for rat plasma (10) and obviously different from the result for bovine serum. It seems that the Se distribution in serum proteins depends on the species.

Selenium distribution in human serum is affected by Se intake and Se metabolism in the human body. Previous research has shown that the percentage selenium associated with glutathione peroxidase in total erythrocyte selenium was relatively higher with the decrease in blood Se concentration (30). The incorporation of selenium into selenoprotein P was preferred to that into plasma glutathione peroxidase when supplemented with Se for selenium-deficient rats (31). For the four individuals in our investigation, the Se amount in selenoprotein $\mathrm{P}$ and the $47 \pm 2 \mathrm{kDa}$ protein could be dependent on the body Se level. The higher percentage of Se in the $47 \pm 2 \mathrm{kDa}$ protein and lower percentage of Se in selenoprotein P were associated with the higher serum Se level. It must be pointed out that the distribution pattern is only a preliminary conclusion. Four human specimens are not enough to have biological meaning in the present results. To 
Table 4

Distribution of Selenium-Containing Proteins in Plasma (Serum)

\begin{tabular}{cccccc}
\hline Sample & Albumin & Selenoprotein-P & p_GPx & $40-42 \mathrm{kDa}$ & Reference \\
\hline Human & $9 \pm 4$ & $52 \pm 6$ & $39 \pm 6$ & 12 \\
plasma/serum & 12 & 60 & 28 & 10 \\
Rat plasma & $12 \pm 2$ & $34 \pm 2$ & $54 \pm 3$ & 12 \\
bovine serum & $16.1 \pm 2.0$ & $61.4 \pm 2.4$ & $23.4 \pm 1.6$ & 13 \\
Human plasma & $7.5 \pm 1.8$ & $54.6 \pm 5.5$ & $22.6 \pm 1.5$ & $14.6 \pm 3.1$ & This paper $^{\mathrm{a}}$ \\
Human serum & & & & \\
\hline
\end{tabular}

a The data in this article was the Se percent in each selenium-containing proteins to the total recovered Se. The data of selenoprotein-P were the sum of two proteins with a MW of $57.5 \pm 2.5 \mathrm{kDa}$ and $47 \pm 2 \mathrm{kDa}$, respectively.

investigate the Se distribution pattern, its biological significance, and the relationship of selenium with human health, further studies on more samples of different Se levels are necessary.

The total Se recovered from visualized bands was from $77.9 \%$ to $90.3 \%$ (see Table 3), which was in good agreement with the values reported previously (i.e., more than $80 \%$ of the whole-body Se was associated with proteins) (1). Other forms of Se might be present in small molecules, such as selenoamino acids, selenide, and so forth. For example, in human liver, about $23 \%$ of total Se exists in small molecules $(M W<2000)$ (14). Selenoamino acids, small selenium-containing molecules, as well as loosely associated selenium in proteins could not be recovered from the collected fractions during the SDS-PAGE procedure. Only the covalently bounded selenium in proteins could be detected and it resulted in Se recoveries of $77.9-90.3 \%$. On the other hand, the procedure could distinguish specific bounded Se from other ones.

The distribution of selenium-containing proteins in human serum was studied by combining preparative SDS-PAGE with microwave digestion and HPLC-FLD. The preparative SDS-PAGE used in the procedure allows larger amount of samples to be separated; also, the technique improves the separating resolution for interested proteins, benefiting the subsequent Se measurement. Furthermore, the merits of pressurized acid digestion in a closed vessel with microwave heating, particularly the decreased sample contamination resulting from the environment make the detection limit decrease to about one-tenth of the previous method (16); 
precise information about distribution of selenium-containing proteins is, thus, available. It is significant to the studies on the relationship of selenium with the Se-responsive diseases.

\section{ACKNOWLEDGMENTS}

This work is supported by the National Natural Science Foundation of China (29977024) and Chinese Academy of Sciences (KZ951-B $\left.{ }_{1}-204\right)$.

\section{REFERENCES}

1 W. C. Hawkes, E. C. Wilhelmsen, and A. L. Tapple, Subcellular distribution of selenium-containing proteins in the rat, J. Inorg. Biochem. 23, 77-92 (1985).

2 T. C. Stadtman, Selenocysteine, Annu. Rev. Biochem. 65, 83-100 (1996).

3. L. A. Daniels, Selenium metabolism and bioavailability, Biol. Trace Element Res. 54, 185-199 (1996).

4 K. G. Danielson and M. Medina, Distribution of selenoproteins in mouse mammary epithelial cells in vitro and in vivo, Cancer Res. 46, 4582-4589 (1986).

5 D. Behne, H. Hilmert, S. Scheid, et al., Evidence for specific selenium target tissues and new biologically important selenoproteins, Biochim. Biophys. Acta 966, 12-21 (1988).

6. D. Behne, A. Kuriakopoeulos, C. Weiss-Nowak, et al., Newly found selenium-containing proteins in the tissues of the rat, Biol. Trace Element Res. 55, 99-110 (1996).

7. M. Sandholm, Function of erythrocytes in attaching selenite-Se onto specific plasma proteins, Acta Pharamcol. Toxicol. 36, 321-327 (1975).

8 J. A. Butler, C. D. Thomson, P. D. Whanger, et al., Selenium distribution in blood fractions of New Zealand women taking organic or inorganic selenium, Am. J. Clin. Nutr. 53, 748-754 (1991).

9. B. Akesson and B. Martensson, Chromatography of selenoproteins in human serum using matrix-bound heparin, Int. J. Vitam. Nutr. Res. 61, 72-76 (1991).

10 J. T. Deagen, J. A. Butler, B. A. Zachara, et al., Determination of the distribution of selenium between glutathione peroxidase, selenoprotein $\mathrm{P}$, and albumin in plasma, Anal. Biochem. 208, 176-181 (1993).

11 W. Huang and B. Akesson, Radioimmunoassay of glutathione peroxidase in human serum, Clin. Chim. Acta 219, 139-148 (1993).

12 I. Harrison, D. Littlejohn, and G. S. Fell, Distribution of selenium in human blood plasma and serum, Analyst 121, 189-194 (1996).

13 T. Plecko, S. Nordmann, M. Rkgauer, et al., Determination and distribution of human plasma selenoproteins, Fresenius J. Anal. Chem. 363, 517-519 (1999).

14 C. Y. Chen, P. Q. Zhang, X. L. Hou, et al., Subcellular distribution of selenium and Secontaining proteins in human liver, Biochim. Biophy. Acta 1427, 205-215 (1999).

15 Z. Wang, S. M. Xie, and A. Peng, Distribution of Se in soybean samples with different Se concentration, J. Agric. Food Chem. 44, $2754-2759$ (1996).

16 Y. X. Gao and Z. Wang, Separation and detection of selenium-containing proteins in human serum, Fresenius J. Anal. Chem. 367, 60-64 (2000).

17 Z. Wang, Y. X. Gao, and N. Belzile, Microwave digestion of environmental and natural waters for selenium speciaton, Anal. Chem. 73, 4711-4716 (2001).

18 U. K. Laemmli, Cleavage of structural proteins during the assembly of the head of bacteriophage T4, Nature 227, 680-685 (1970). 
19. J. H. Morrisey, Silver stain for proteins in polyacrylamide gels: a modified procedure with enhanced uniform sensitivity, Anal. Biochem. 117, 307-310 (1981).

20. B. A. Zachara, Mammalian selenoprotein, J. Trace Elements Electrolytes Health Dis. 6, 137-151 (1992).

21 J. R. Arthur and G. J. Beckett, New metabolic roles for selenium, Proc. Nutr. Soc. 53, 615-624 (1994).

22 C. D. Thomson, Selenium speciation in human body fluid, Analyst 123, 827-831 (1998).

23 Y. Shiobara and K. T. Suzuki, Binding of selenium (administered as selenite) to albumin after efflux from red blood cells, J. Chromatogr. B 710, 49-56 (1998).

24 K. T. Suzuki and M. Itoh, Metabolism of selenite labelled with enriched stable isotope in the bloodstream, J. Chromatogr. B 692, 15-22 (1997).

25. S. Himeno, H. S. Chittum, and R. F. Burk, Isoforms of selenoprotein P in rat plasma. Evidence for a full-length form and another form that terminates at the second UGA in the open reading frame, J. Biol. Chem. 271, 15,769-15,775 (1996).

26 H. S. Chittum, S. Himeno, K. E. Hill, et al., Multiple forms of selenoprotein P in rat plasma, Arch. Biochem. Biophys. 325, 124-128 (1996).

27 K. E. Hill and R. F. Burk, Selenoprotein P: recent studies in rats and in humans, Biomed. Environ. Sci. 10, 198-208 (1997).

28 V. Mostert, I. Lombeck, and J. Abel, A novel method for the purification of selenoprotein P from human plasma, Arch. Biochem. Biophys. 357, 326-330 (1998).

29 B. Akesson, T. Bellew, and R. F. Burk, Purification of selenoprotein P from human plasma, Biochim. Biophys. Acta 1204, 243-249 (1994).

30. P. D. Whanger, Y. Xia, and C. D. Thomson, Protein technics for selenium speciation in human body fluids, J. Trace Elements Electrolytes Health Dis. 8, 1-7 (1994).

31. R. F. Burk, K. E. Hill, R. Read, et al., Response of rat selenoprotein P to selenium administration and fate of its selenium, Am. J. Physiol. 261, 26-30 (1991). 